\title{
NAZI NATIONAL POLICY TOWARDS THE RUSSIAN MINORITY IN THE BALTIC STATES
}

The paper examines the position of the Russian minority in the Baltic States during the Nazi occupation. It argues that the Russians in the Baltic region experienced a higher level of discrimination than the local inhabitants, and it explores the reasons for such inequity. One of them lay in the strong antiRussian sentiment shared by the Baltic local authorities, who aimed to use the German occupation to suppress the Russian minority. Another one was the complex and confused structure of the German occupation authorities in the Baltic region, with many political actors (such as the Ministry for the Occupied Eastern Territories, the Office for the Four Year Plan, Himmler's police units, the Wehrmacht and finally the local administrations) struggling for power there. Such entanglements resulted in the inconsistency of the German policy in racial and administrative issues including their attitude toward the Russian minority. While the higher echelons of Nazi power, police and the local authorities insisted on the extermination of the Slavs as Untermenschen, the German civilian administration of the lower level considered Russians to be a useful instrument in the fight against the local Baltic administrations, over which they had been losing control. However, the attempts to involve Russians in German policy failed due to a lack of coordination between the different branches of Nazi power and as a result of the growing guerrilla movement which involved many Russian inhabitants of the Baltic States. Refs 60.

Keywords: Reichskommissariat Ostland, Third Reich, Eastern Front, Untermenschen, Latvia, Estonia, Lithuania, Latgale, Generalplan Ost, forced labour, Ostarbeiters.

For citation: Plath T. Nazi national policy towards the Russian minority in the Baltic States. Vestnik of Saint Petersburg University. History, 2017, vol. 62, issue 1, pp. 120-130. DOI: 10.21638/11701/ spbu02.2017.110

\section{Т. Плат}

\section{РУССКОЕ МЕНЬШИНСТВО В НАЦИСТСКОЙ ПОЛИТИКЕ В ПРИБАЛТИКЕ}

В статье рассматривается положение русского меньшинства в Прибалтике во время нацистской оккупации. В этом регионе русское население подвергалось бо́льшим преследованиям, чем представители местных народов, и цель данного исследования - проанализировать причины этого неравенства. Как показано в статье, одна из них заключалась в том, что среди местных прибалтийских властей были распространены сильные антирусские настроения и потому они пытались использовать немецкую оккупацию, чтобы избавиться от русских меньшинств на своей территории. Еще одной причиной неравноправного положения населения Прибалтики стала запутанная система управления немецких оккупационных властей, участники которой боролись друг с другом за влияние в этом регионе (Министерство оккупированных восточных территорий, Ведомство Четырехлетнего плана, полицейский аппарат Гиммлера, Вермахт и, наконец, местные земельные администрации). Следствием этой сложной структуры стала непоследовательность в расовой, идеологической и административной политике, в том числе и по отношению к русскому меньшинству. В то время как высшие нацистские чины, полиция и местные власти выступали за истребление славянского населения, низовая немецкая гражданская администрация полагала, что русские могут стать удобным инструментом в борьбе против прибалтийских земельных властей, которые становились все менее контролируемыми. Однако попытки включить русских в управление оккупированными территориями потерпели крах, во-первых, из-за несогласованности между разными ветвями нацистской власти, и, во-вторых, вследствие растущего партизанского движения, которое

Plath Tilman - PhD in History, Wissenschaftlicher Mitarbeiter, Ernst Moritz Arndt University of Greifswald, Rubenow Str. 2, Greifswald, 17487, Federal Republic of Germany; platht@uni-greifswald.de

Плат Тильман - PhD, научный сотрудник, Грайфсвальдский университет им. Э. М. Арндта, Федеративная Республика Германия, 17487, Грайфсвальд, Рубеновштрасе, 2; platht@uni-greifswald.de

(C) Санкт-Петербургский государственный университет, 2017 
привлекало все больше представителей русского меньшинства, проживавшего на территории Прибалтики. Библиогр. 60 назв.

Ключевые слова: Рейхскомиссариат «Остланд», Третий рейх, Восточный фронт, Латвия, Эстония, Литва, Латгалия, Генеральный план Ост, остарбайтеры.

The Baltic States fell under rule of Nazi Germany as a result of the Wehrmacht's offensive against the Soviet Union launched in the summer of $1941^{1}$. The campaign on the Eastern Front was initially planned as a war of annihilation ${ }^{2}$. Therefore, the mass executions of the Jews, Communists and Soviet activists began immediately in the rear of the attacking German army, carried out by the Einsatzgruppen of the Reich Main Security Office, police battalions and the units of the Wehrmacht ${ }^{3}$. In addition to the above-mentioned groups subjected to extermination, further planning anticipated a reduction of the Russian population by 'a few million' through firing squad and starvation ${ }^{4}$. After the occupation, the Russian minority in the Baltic States found itself in a quite uncertain situation. On the one hand, it benefited from the fact that the Baltic region had been less damaged and that the Nazi invaders persecuted its population less heavily, as according to their planning, a special status was to be granted to the Baltic States in the anticipated post-war political and racial order ${ }^{5}$. On the other hand, the Russians were under the sway of the invaders, whose policy in this region was largely determined by racist ideology. Such contradiction can be explained by the overall inconsistency of the Nazi occupation policy. Two contradictory opinions suggesting different ways of treating Russian minority in the Baltic States may clearly illustrate this ambiguity.

The first example might be derived by the words of the Gebietskommissar of Daugavpils Friedrich Schwung, who described the position of the Russians in his district in the following way. "An accurate assessment of reality allows one to conclude that, regarding their working skills, the Russians are absolute equals to the Latvians. Moreover, we can admit that the Russian peasants cultivate their lands in a better and more intensive way than the Latvians" [LVVA-P-69.1a.18 1942, pp. 485-497].

The opposite opinion had been voiced at the special meeting concerning the future of the 'racially undesirable elements' and the abilities of "the Ostland nations to be Germanised". Concerning the plans for the Slavic minority, the following was suggested, "It might be considered that in order to meet the requirements of the planned industrialization, it would be more appropriate to scrap the whole racially undesired part of the population"6.

The contradictions in plans for the Russian minority in the Baltic States need to be clarified. In order to do so, two factors should be taken into consideration. First, it is necessary to reveal the Nazis' objectives and to outline the political structure of the occupation authorities in the Baltic region. Next, it must be recognized that the consequences for the Russian minority were brought about by a specific combination of German political

${ }^{1}$ For the German occupation of the Baltic States, see [Das Deutsche 1983, Haupt 1963].

2 Historiography of this issue is covered in [Müller 2009].

${ }^{3}$ For the Holocaust in the Baltic States, see: [Benz 2012, pp. 35-50], for the Einsatzgroups: [Wilhelm 1996].

${ }^{4}$ Quoted from [Aktennotiz 1948, p. 48].

5 The occupation policy in the Baltic States is explored by [Myllyniemi 1973; Gräfe 2010].

6 The minutes of the meeting on the 'Germanization of the Baltic countries' held at Dr. Kleist's, an official of the Ministry for the Occupied Eastern Territories (4.2.1942). The minutes were published in [Heiber 1958, pp. 281-325]. 
planning and the actual structure of occupational authorities in the Baltic States. This situation will be clearly illustrated by the manner of recruitment for the forced labour applied to the Russian minority and the rest of the Baltic population.

The German occupation of the Baltic countries in 1941 resulted in almost four hundred thousand Russians falling under the rule of Nazi invaders. The largest part of the Russian minority dwelled in Latvia, making up $12 \%$ of the Latvian population and a half of the overall number of Russians living in the Baltic region. In Latvia itself, Russians concentrated mainly in Riga and in the Eastern district of Latgale [Myllyniemi 1973, p. 293]. In Estonia and Lithuania, the Russian population was similarly located on the Eastern borderlands, for example, near the border of Smolensk Oblast in the southeast of Estonia (close to the district of Pechora).

What was to happen to these Russians under the authority of the conquerors? It is widely considered that the German occupation of the Baltic States should not be separated from the war of annihilation against the Soviet Union. Indeed, according to the General Plan 'Ost' and other plans of colonization, this region was earmarked for colonization and enslavement [Myllyniemi 1973, pp. 157-160]. However, leaving aside regional differences between various units of the occupied Soviet territories at this point, an important criterion should be considered. It is a fact that the German visions of occupation were by no means homogeneous but varied considerably, and it plainly demonstrates that the German occupation policy in the Baltic countries had not been made uniform. Who were those makers of the German occupation policy, the main characters in charge of taking decisions?

As far as the administrative structure is concerned, the three Baltic countries, which had lost their sovereignty due to the implementation of the Molotov-Ribbentrop Pact ${ }^{7}$, and a part of Belarus were incorporated in the so-called Reichskommissariat Ostland ${ }^{8}$. The latter, along with Reichskommissariat Ukraine, was subjected to the Reich Ministry for the Occupied Eastern Territories headed by Alfred Rosenberg, who originated from Tallinn himself ${ }^{9}$. Hitler appointed the Gauleiter of Schleswig-Holstein Hinrich Lohse as Reichskommissar of Ostland ${ }^{10}$. The Three Baltic States constituted three General Commissariats, which were subdivided into regional (Gebietskommissariats) and municipal (Stadtkommissariats) Commissariats ${ }^{11}$.

Rosenberg's wish to control the civilian administration was single-handedly counteracted by other political actors, thus significantly restraining his power ${ }^{12}$. One of the main reasons for that was the German administration lacking the governing officials in this region and therefore obliged to give greater scope to local personnel. This is why each of three Baltic general Commissariats had a territorial administration. These authorities could maintain at least the semblance of autonomy, which was pursued by the Baltic politicians, who desired the restoration of independence. Even though the territorial admin-

\footnotetext{
7 For the earlier history of the Baltic States, see [Garleff 2001].

8 For Reichskommissariat Ostland, see [Reichskommissariat 2012], for Estonia see [Estonia 2006], for Latvia see [Felder 2009; Jüngerkes 2010; Lumans 2006], for Lithuania see [Dieckmann 2011].

9 For the role of Rosenberg, see: [Piper 2007].

10 The role of Lohse is analyzed in: [Danker 1998; Danker 1999].

11 For the structure of administration, see: [Myllyniemi 1973, pp. 87-96].

12 For the main issues, see: [Zellhuber 2006].
} 
istrations were not vested with the power to take final decisions, still they could set their political priorities in certain issues ${ }^{13}$.

In addition to the limitations imposed by the local administrations on the German authorities, the controversies in the Baltic region were also fuelled by the political struggle within the Nazi governing clique itself, launched with the establishment of the Ministry for the Occupied Eastern Territories in Berlin in 1941. The authority of Nazi civilian administration was challenged by the Plenipotentiary of the Office of the Four Year Plan, Hermann Göring, who aimed to keep the full control over economics even after the civilian administration was established. However, the latter faced the strongest competition from the Himmler's police machinery. It was the Higher SS and Police Leader (HSSPF) of Ostland and Northern Russia, Friedrich Jeckeln, who obtained significant control over the civil population and who was only formally subordinated to the Reichskomissariat of Ostland [Zellhuber 2006, pp. 263-291]. It should also be remembered that due to the close proximity to the Eastern Front, the top military of the Wehrmacht had their special jurisdiction there, which had been implemented by the Supreme Military Commander (Wehrmachtbefehlshaber) of Ostland, Walter Braemer [BA-R-6.209 1941, p. 1].

Thus, how did this polyarchic structure influence the Russian minority? In other words, what specific interests and what racial and ideological objectives did the abovementioned actors pursue; to what extent were these objectives accomplished? ${ }^{14}$ In this regard, the key question to be answered is how profound the differences between the Russian minority and the locals were and how the occupants took advantage of them. Although during the war no single regulation was issued to state a division between the two population groups, this does not necessarily mean that this issue did not have any impact on the long-term planning. Available sources such as memoranda and directives may reveal the following picture ${ }^{15}$. The top management of the Office of the Four Year Plan and the Wehrmacht had been exceptionally pragmatic in their orientation and were not interested in the extermination of the Slavic minority, which they merely regarded as a labour force ${ }^{16}$. On the contrary, the civilian administration tended to highlight the differences within the population. This administration pursued the racist and ideological goals and therefore tended to place stronger emphasis on differences between Baltic and Slavic people than the General and especially Regional Commissars did. Moreover, the racist and ideological objectives were kept under the seal of secrecy, so that they were discussed only at Reichskommissariat level [BA-R-6.160 1943b, pp. 108-110]. However, the fact that lower echelons of administration being more pragmatic and even initially favouring the Russian minority does not mean that it ignored the racist logic of the higher authorities ${ }^{17}$.

In order to reveal the complete picture of racial and ideological features of occupation policy in the Baltic States, the role of the local Baltic authorities should be considered. The latter was comprised of the officials who had been holding their posts since the interwar

13 The jurisdiction of the local administration Lithuania is represented in [(BA-MA)-RW-30.206 1942].

14 For the term and discussion on the 'polyarchy' in the Baltic States from 1941-1944, see [Jüngerkes 2011, pp. 275-298].

${ }_{15}$ For example, [BA-R-6.159 Undatiert, pp. 4-7; LVVA-P-69.1a.9 1942, p. 12; LVVA-P-69.1a.6 1943, pp. 186-194; BA-R-6.160 1943a, p. 98; LVVA-P-70.5.89 Undatiert, pp. 6-11].

16 Quoted from: [Czollek 1974, p. 169].

17 For example, the Gebietskommissar of Daugavpils called the local population 'The grown-up children of the East' [LVVA-P-69.1a.18 1942, pp. 168-273]. 
period; the traditional anti-Slavic policy had thus been preserved ${ }^{18}$. The local officials of each of the three Baltic States had continually been using occupation authorities for oppressing the Slavic minorities, especially in the Eastern districts bordering Russia, where the ethnic conflicts had long been smouldering and determined the political climate there $^{19}$. For example, the representatives of the Slavic minority in Lithuania described the local Lithuanian government in the following way. "We Russians who had been living in Lithuania for a long time were plunged into a difficult situation. After the expulsion of the Communists, we were to face the worst. The Lithuanians want to turn us into a part of their own people; they want us to accept their 'superior' culture. They would not understand why we refuse to assume their likeness and deny our own ancestors" [BA-R6.159 1943].

It is remarkable that the police machinery, permeated with racist principles, almost never took into consideration the theoretical differences between the Baltic and Slavic people. The SS ideological doctrine of Untermenschen did not draw any significant line between the ethnic origins of the nations living on the Eastern occupied territories; this is clearly illustrated by the fact that the SS experts assumed a much lower percentage of people to be liable to Germanization than the officials of the civil administration did [Mēs apsudzam 1965, pp. 15-17].

The outlined variations in the views of different actors on the racial and ideological doctrines are merely statistical, while their racist policy entirely depended on the outcome of the war. That was the reason why during the period of occupation and especially during 1942-1943 the priorities the Nazi policy had somehow shifted from following the strategic goals to implementing the tactical objectives of occupation [Myllyniemi 1973, pp. 206-208]. While the Baltic region was widely dreamt of as a future German colony during the first years of occupation, in the second half of the war the primary concern of German authorities was to pillage the largest possible amount of resources of any kind. This turn had induced a change in the attitude towards the Russian minority. The racist ideology of the civilian administration began to matter less, while more efforts were being applied to exploit the Russian population for the Reich's needs. However, those plans failed because the police had already started to persecute Russians who allegedly supported the guerrilla movement. The German civilian administration and especially its lower ranks gradually grew disappointed in the perspectives of collaboration with the local Baltic authorities, as it was getting more and more difficult to control them. Moreover, the Germans tried to involve the Russians in their strategic struggle against Baltic separatism. As a result, the Russian consultative committees (Vertrauensrät) were instituted at the level of Gebietskommissariats in order to represent the interests of the Russian minority in proportion to their ratio in the native population [ERA-R. 65.1.43 Undatiert, p. 6]. Needless to say, these measures were vigorously opposed by the local Baltic authorities ${ }^{20}$. These committees continued to exist, although they remained under direct control of the local administration due to the lack of embeddedness in the local political structures. Another factor behind the failure of the attempt to establish Russian self-government was the crucial turn in the military campaign. The guerrilla movement had been involving an increasing number of Russian volunteers and that dimmed to prospects of further collaboration between Ger-

\footnotetext{
${ }^{18}$ For this issue, see: [Nationale 2009].

19 For Latgale in Latvia, see: [Plath 2012, p. 101-116].

${ }^{20}$ For example, [LVVA-P-69.1a.29 1944, p. 196].
} 
man occupation authorities and Russian self-governments. The major anti-partisan punitive operations included 'Winterzauber', 'Sommerreise', 'Heinrich'21 or long-lasting warfare near Vilnius in which the partisans of the Polish Armia Krajowa largely participated [BAR-90.125 1944]. The police units had no scruples in exterminating whole Russian villages, as happened in the case of the village of Audrini in Latgale where 235 inhabitants were killed $^{22}$. However, while the turn of the war influenced the policy of the local administration and police, the higher officials of the Four Year Plan Office and Wehrmacht authorities did not not alter their strategy's racial logic.

Real interests and objectives of the actors on the Russian minority in the Baltic region might be illustrated by how the conscription of Russians for forced labour in Germany was implemented. The discrimination suffered by the Russian minority is plainly evident from its comparison with the other ethnic communities potentially liable to be recruited to Germany to work for the Reich. In this regard, the population of the Baltic States might be divided into four groups: firstly, there was the native population, i.e. Estonians, Latvians, and Lithuanians. Secondly, there were Russian and Slavic minorities, which included the local Russians, prisoners of war and 'Ostarbeiters'. The latter were comprised mostly of the Ukrainian POWs but also of so-called 'Evarussen' - nearly 500,000 Russians who were evacuated (some of them voluntarily and the others forced) from the East to the Baltic region while running from the offensive of the Red Army in $1943^{23}$. Thirdly and fourthly, the Jews (which have not yet been considered in this article) ${ }^{24}$ and Romani groups could also be used as coercive labour.

The recruitment of these groups was implemented differently. In the very beginning of occupation, many Estonian, Latvian and Lithuanian workers had voluntarily moved to Germany ${ }^{25}$ within the Reich Labour Service (RAD) [LVVA-P-70.3.12 1942, p.4] programme, since they believed that such a work would further their future Germanization. Thus, the forced labour was considered to be a part of a special "training, which could prepare young workers for accepting the Nazi outlook and order" [LVVA-P-70.3.12 1942, p.4], rather than just an industrious contribution to the Reich. Although since the beginning of the war, the RAD had used harsh methods in recruiting, its policy still differed drastically from the aggressive ways in which conscription into forced labour was organized by the General Plenipotentiary for Labour Deployment Fritz Sauckel ${ }^{26}$. The infamous violent 'Sauckel actions', carried out from the spring of 1942, had become a result of the need to significantly increase the number of foreign workers in Germany ${ }^{27}$. The Baltic local administration preferred to supply the manpower required by Sauckel from the districts where the Russian population prevailed, with the workers being obtained by extremely harsh methods. The single 'Latgale action' brought 8,000 workers to Germany [BA-R-70.Sowjetunion.20 1942; Swain 2004, pp. 90-93]. The fact that it was initiated directly by the local Baltic authorities is confirmed by the minutes of operational planning.

\footnotetext{
${ }^{21}$ See [Kangeris 2004, pp. 332-357].

22 See: [LVA-101.6.20 p. 5; Šteimanis 2003, p. 66].

${ }^{23}$ For the phenomenon of Evarussen, see: [Müller 1994, pp. 42-76].

24 For the Jewish forced labour in the Baltic region, see [Angrick 2006; Weiss-Wendt 2009].

25 There were several hundred Estonian workers and several thousand Lithuanian ones; later many of them were forced to stay in Germany. See [Braslauskas 2005, pp. 38-59; LCVA-R-626.1.16 1941, p. 28; BAMA-RW-30.1 1941, pp. 58-59; Rüstungsinspektion 1941, p. 62].

${ }^{26}$ See [Raßloff 2008].

27 For the expanding of forced recruiting to Germany from 1942, see [Herbert 1999, pp. 157-160].
} 
For example, the plans of 'Latgale action' stated the following: "It was he [the Latvian General Oskars Dankers], who ordered to recruit the required labour force in Latgale without being instructed from the German side, just on the ground that Latgale was anyway inhabited by a large number of foreigners" [Institut für Zeitgeschichte 1942, pp. 1202-1219; Kangeris 1990, p. 39].

From 1943, this policy had been implemented more widely as a response to the spread of the guerrilla movement, the participation in which could be punished by forced labour exile to Germany. Thousands of people who were lucky enough not to get killed during the anti-partisan police operations were sent to Germany for coercive labour ${ }^{28}$. The lower echelons of civilian administration applied some efforts to prevent the worsening of the attitude toward the Russian minority, but in vain. It is remarkable that the complaints of the lower civilian officials were not heeded even in the cases when the anti-Russian policy of the local authorities hampered German interests. Such an attitude is clearly revealed in the report submitted by the official responsible for the labour conscription in Daugavpils: "We have annihilated the Jews for you, and we kept the same stance on the Old Believers and the Poles. Now we face the problem of the Russians. They also should be moved out of Latgale. The Latvians will strive hard in close collaboration with the German forces in order to reach this aim which they have been aspiring to achieve over the last twenty years" [LVVA-P-69.1a.18 1942, pp. 485-497].

The anti-Russian strategy revealed itself in a similar way in the policy of Estonian and Lithuanian local administrations. For example, in Lithuania, the Germans were widely regarded as defenders of Russians from the despotic local Lithuanian authorities ${ }^{29}$. In Estonia, until the very end, the local officials had been attempting to deport the whole Russian minority under the guise of labour conscription [ERA-R. 65.1.43 1944, p. 18].

Thus, it was too late when the lower echelon of the German civilian administration had realized that the Russian minority could be their ally against the local Baltic authorities, which gradually became more prominent while the occupant power weakened. By that time, the anti-Russian policy of the local Baltic administration and the upper level of German occupation authorities had gone too far, and it was no longer possible to involve the Russians in the governing of the Baltic region. The attempts to establish Russian police battalions similarly failed ${ }^{30}$. These efforts to involve Russians were doomed to be unsuccessful for two reasons: firstly, the police had a priority over the civil administration, and secondly, numerous anti-partisan operations were directed primarily against the Slavic population. These factors made any voluntary recruitment of Russians to serve in the administration virtually impossible.

It might be concluded that during the whole period of occupation, the Russians in the Baltic States by no means possessed the equal rights with the local people, even though they were considered formally to be equal. The reason for that was the German civilian administration adhering strictly to racial and ideological goals, and therefore approved

${ }^{28}$ In the autumn of 1944, there were overall 130,000 Baltic workers in Germany, the largest part of whom were Russians from the Eastern Baltic borderlands [Kangeris 2010, p. 43 f.].

29 "They [the Russian minority] regarded the Germans as their defenders; meanwhile, there local authorities consisted mostly of the Lithuanians". See: [BA-R-6.159 1944, p. 68f.].

30 See: [Latvija 2008, p. 347 f.]. For the phenomenon of the Russian collaborationism in Latgale see: [Nikolaevič 2008, pp. 60-64]. 
the policy of the local Baltic authorities. Later, after the turn in the war in winter 1942-43, the priorities of the German civilian administration changed in favour of the Russians; but at the same time the powerful police institutions started to pursue even harsher antiRussian policy. This is why the fate of the Russian population differed so radically from the destiny shared by local inhabitants. The discrimination the Russians faced with in the issues of conscription to the forced labour in Germany, persecutions of the guerrillas, and lack of representation in the local authorities plainly illustrates this difference. If the German occupation policy in the Baltic region is to be compared to the German policy in other territories, the criminal actions of the German occupants towards the Russian population could be regarded just as another example of the suffering and loss Russian civilians had to endure during the war of annihilation led by the Third Reich on the Eastern Front.

\section{References}

Aktennotiz über Ergebnis der heutigen Besprechung mit den Staatssekretären über "Barbarossa", 2. Mai 1941 [Memo about the outcome of today's discussion with the Secretaries of State on "Barbarossa"]. Der Prozess gegen die Hauptkriegsverbrecher vor dem Internationalen Militärgerichtshof. Nürnberg, 14. November 1945 - 1. Oktober 1946 (IMT) [International Military Tribunal in Nürnberg, 14. November 1945]. Vol.1. Nuremberg, Sekretariat d. Gerichtshofes unter d. Autorität d.Obersten Kontrollrats [Secretariat of the Court under the authority of the Supreme Council], 1948, p. 84, dok. 2718-PS. (In German)

Angrick A., Klein P. Die "Endlösung" in Riga. Ausbeutung und Vernichtung 1941-1944 [The "Final Solution" in Riga. Exploitation and extinction 1941-1944]. Darmstadt, Wissenschaftliche Buchgesellschaft [Scientific Academic Society Publ. ], 2006, 520 p. (In German)

Organisationserlaß Ostland Nr. 1: Richtlinien für die Führung der Verwaltung im Generalbezirk Litauen [Organizational Decree Ostland no 1: Guidelines for the management of the administration in the general district of Lithuania]. Bundesarchiv-Militärarchiv Freiburg [Federal Military Archive] (BAMA), RW-30.206 u.p. Reichsminister für die besetzten Ostgebiete [Reich Ministry for the Occupied Eastern Territories] (RMfdbO) Rosenberg, 7.3.1942. (In German, unpublished)

Dienststelle Rosenberg, Denkschrift zur Behandlung der indigenen Völker [Office Rosenberg, Memorandum for the treatment of indigenous peoples]. Bundesarchiv Berlin [Federal Archive Berlin] (BA), R-6.159, p. 4-7. Undated. (In German, unpublished)

Reichskommissar für das Ostland (RKO) Abteilung I Politik (Abt. I Pol.), Trampedach, Schreiben betr.: Russische Volksgruppe im Generalbezirk Litauen. RMfdbO [Reichskommissariat Ostland Political Departement i Trampedach, Letter regarding the Issue of the Russian Minority in Lithuania. 23.5.1944. Bundesarchiv Berlin [Federal Archive Berlin] (BA), R-6.159, p. 68.f. (In German, unpublished)

Auslandsbriefprüfstelle im Wehrkreis I, Schreiben betr.: Russen beklagen sich über die Unterdrückung durch die Litauer, An: Oberkommando der Wehrmacht Amt Auslandsabwehr (OKW Amt Ausl./ Abwehr) [International Letter Examination Office in the Military District I, Letter concerning the Rusians' complaint about suppression on part of Lithuanians, Addressee: High Army Command, Department for Foreign Intelligence Service]. 18.9.1943. Bundesarchiv Berlin [Federal Archive Berlin] (BA), R-6.159 u.p. (In German, unpublished)

RMfdbO Dr. Wetzel, Zur Frage der Eindeutschbarkeit der Esten, Letten und Litauer, An: RKO [RMfdbO Dr. Wetzel, Concerning the question of Germanization of the Estonians, Latvians and Lithuanians, Addressee: RKO]. May 1943. Bundesarchiv Berlin [Federal Archive Berlin] (BA), R-6.160, p.98. (In German, unpublished)

RMfdbO Dr. Wetzel, Schreiben betr.: Richtlinien zur Frage der Eindeutschbarkeit der Esten, Letten und Litauer. An: Dr. Leibbrandt, [RMfdbO Dr. Wetzel, Letter concerning the guidelines about the Germanization of the Estonians, Latvians and Lithuanians, Addressee: Dr. Leibbrand]. 3.5.1943. Bundesarchiv Berlin [Federal Archive Berlin] (BA), R-6.160, pp. 108-110. (In German, unpublished)

Erlass des Führers betr. Wehrmachtsbefehlshaber [Decree by Hitler concerning the Army commanders]. 25.6.1941. Bundesarchiv Berlin [Federal Archive Berlin] (BA), R-6.209, p. 1. (In German, unpublished)

SS und Polizeiführer in Dünaburg, Lage- und Erfahrungsbericht über die Aktion des SD im Gebiet Lettgallen zur Gewinnung von Arbeitskräften. An: Kommandeur der Gendarmerie Lettland [SS and Police commander in Dvinsk, Report about the Labour force action in Latgale, Addressee: 
Commander of the Police in Latvia]. 19.5.1942. Bundesarchiv Berlin [Federal Archive Berlin] (BA), R-70.Sowjetunion.20 u.p. (In German, unpublished)

Karte der "Bandentätigkeit in Litauen 1944 [Map of the Partisanwarfare in Lithuania 1944]. Bundesarchiv Berlin [Federal Archive Berlin] (BA), R-90.125 u.p. (In German, unpublished)

Sicherheitspolizei und SD, Bericht betr.: Politische Haltung der Polen in Litauen [Secretservice and Police, Report about the political attitude of the Poles in Lithuania]. 1.5.1944. Bundesarchiv Berlin [Federal Archive Berlin] (BA), R-6.75, pp. 81-85. (In German, unpublished)

Muster für die Satzung einer Vertrauenstellen einer Volksgruppe [Pattern for a statute for a Council of minorities] Bundesarchiv Berlin [Federal Archive Berlin] (BA), R-6.159 p. 25.f. (In German, unpublished)

Benz W. Im Schatten von Auschwitz? Der Holocaust im Baltikum [In the shadow of Auschwitz? The Holocaust in the Baltic Countries]. Reichskommissariat Ostland. Tatort und Erinnerungsobjekt [Reichscommissariat Ostland. Site of crime and memory]. Ed. by Sebastian Lehmann. Vol. 8. Paderborn, Schöningh Publ., 2012, pp. 35-50. (In German)

Braslauskas J. Okupacine darbo prievoliu politika Lietuvoje 1941-1944 metais [Forced Labour policy in occupied Lithuania in 1941-1944]. Lietuvos istorijos studijos [Historical Studies of Lithuania], 2005, no. 15, pp. 38-59. (In Lithuanian)

Czollek R. Faschismus und Okkupation. Wirtschaftspolitische Zielsetzung u. Praxis des faschistischen dt. Besatzungsregimes in d. baltischen Sowjetrepubliken während d. 2. Weltkrieges [Fascism and Occupation. Economic Goals and practice of the fascist German Occupation regime in the Baltic countries during the Second World War]. Berlin, Akademie-Verlag, 1974, 224 p. (In German)

Danker U. Die drei Leben des Hinrich Lohse [The three lives of Hinrich Lohse]. Demokratische Geschichte [Democratic History], 1998, no. 11, pp. 105-114. (In German)

Danker U. Hinrich Lohse, ${ }^{\star} 1896$ Mühlenbarbek -+1964 Mühlenbarbek Born in 1896 in the City of Mühlenbarbek and died in the City of Mühlenbarbek in 1964: NSDAP-Gauleiter, Oberpräsident, Reichskommissar, Rentner [Nazi-Gauleiter, Regional President, Reichscommissar, Pensioner]. Historische Persönlichkeiten [Historical Personalities], 1999, pp. 280-290. (In German)

Das Deutsche Reich und der Zweite Weltkrieg. Bd. 4. Der Angriff auf die Sowjetunion [The Third Reich and the Second World War, Volume 4, The invasion of the Soviet Union]. Ed. by Andreas Hillgruber. Stuttgart, Deutsche Verlags-Anstalt, 1983, 1192 p. (In German)

Dieckmann C. Deutsche Besatzungspolitik in Litauen 1941-1944 [German occupation policy in Lithuania 1941-1944]. Gottingen, Wallstein Publ., 2011, 1652 p. (In German)

Gebietskommissar in Reval (GK), Schreiben betr.: Russische Vertrauensstelle. An: Stadtkommissar Reval [District Commissar of Reval, Letter concerning the Russian Council, Addressee: City Commissar of Reval. 1.10.1943. Eesti Riigi Arhiiv [Estonian State Archive] (ERA), R.65.1.43 p. (In German, unpublished)

Vertrauensstelle für die russische Volksgruppe im Generalbezirk Estland, Schreiben betr.: Ausweisung von Russen durch estnische Selbstverwaltung. An: Stadtkommissar Reval. [Council of the Russian Minority in the Generaldistrict of Estonia. Letter concerning the expulsion of Russians by the Estonian Local Government, Addressee: City Commissar of Reval. 15.11.1944. Eesti Riigi Arhiiv [Estonian State Archive] (ERA), R. 65.1.43, p. 18. (In German)

Estonia 1940-1945: reports of the Estonian International Commission for the Investigation of Crimes Against Humanity. Ed. by T.Hiio, Tallinn, Estonian Foundation for the Investigation of Crimes Against Humanity Publ., 2006, 1337 p.

Felder B.M. Lettland im Zweiten Weltkrieg. Zwischen sowjetischen und deutschen Besatzern 19401946 [Latvia during the Second World War. Between German and Soviet Occupiers 1940-1946]. Paderborn, Schöningh Paderborn Publ., 2009, 401 p. (In German)

Garleff M. Die baltischen Länder [The Baltic Countries]. Regensburg, Pustet Publ.; Munich, SüdosteuropaGesellschaft Publ. , 2001, 269 p. (In German)

Gräfe K.H. Vom Donnerkreuz zum Hakenkreuz: Die baltischen Staaten zwischen Diktatur und Okkupation [Between Thundercross and Swastika. The Baltic Countries between Dictatorship and Occupation]. Berlin, Edition Organon, 2010, 513 p. (In German)

Haupt W. Baltikum 1941: die Geschichte eines ungelösten Problems [The Baltic Countries 1941: The Story of an unsolved problem]. Neckargemünd, K. Vowinckel Publ., 1963, 200 p. (In German)

Heiber H. Generalplan Ost [Generalplan Ost]. Vierteljahrshefte für Zeitgeschichte [Quarterly for Contemporary History], 1958, 6, part 3, pp. 281-325. (In German)

Herbert U. Fremdarbeiter. Politik und Praxis des "Ausländer-Einsatzes" in der Kriegswirtschaft des Dritten Reiches [Foreign Workers. Policy and practice of the "Foreigner-application" in Third Reich War Industry]. Bonn, J.H. W.Dietz Nachf Publ., 1999, 592 p. (In German) 
Generalkommissar (GK) in Riga [District Commissar in Riga], Vermerk betreffend: Sitzung vom 2.5.1942. Gegenstand der Verhandlung: Abgabe von Kräften ins Reich [Note concerning: meeting of 2.5.1942. Subject of the hearing: Delivering workforce to the Reich]. 4.5.1942. Institut für Zeitgeschichte [Institute for Contemporary History] (IfZ), MA. 202, pp. 1202-1219 (In German, unpublished)

Jüngerkes S. Bürokratie als Stabilisierungs- und Destabilisierungsmechanismus: Das "Reichskommissariat für das Ostland" 1941-1945. Der prekäre Staat. Herrschen und Verwalten im Nationalsozialismus [Bureaucracy as a stabilization and destabilization mechanism: The Reich Commissariat Ostland 19411945. The precarious state. Ruling and administration under national socialism]. Ed. by S. Reichardt. Frankfurt am Main; New York, Campus Verlag, 2011, pp. 275-298. (In German)

Jüngerkes S. Deutsche Besatzungsverwaltung in Lettland 1941-1945. Eine Kommunikations- und Kulturgeschichte nationalsozialistischer Organisationen [German Occupational Administration in Latvia 1941-1945. A Cultural History and History of communication of national socialist organisations]. UVK Verlagsgesellschaft, 2010. vol. 15, pp. 575. (In German)

Kangeris K. Baltische Zwangsarbeiter im Dritten Reich. Hitlers Sklaven - Stalins "Verräter". Aspekte der politisch-administrativen Repressionen an Zwangsarbeitern und Kriegsgefangenen; Eine Zwischenbilanz [Baltic Forced Labourers in the Third Reich. Hitler's Slaves - Stalin's "Traitors". Aspects of politicaladministrative Repression towards Forced Labourers and Prisoners of War. An interim result]. Ed. by P. Ruggenthaler, W. Iber. Vol. 14. Innsbruck, Studien Verlag, 2010, pp. 43-62. (In German)

Kangeris K. Latviešu policijas bataljoni lielajās partizānu apkarošanas akcijās 1942. un 1943.gadā [Latvian Police Battalions during the great antipartisan warfare actions in 1942 and 1943]]. Latvijas Vésturnieku Komisijas Raksti [Articles of the Commission of Latvian Historians], 2004, no. 13, pp. 332-357. (In Latvian)

Kangeris K. Nodeva reiham. Latvijas ǵenerālapgabala iedzīvotāji darbos Lielvācijā [Delivered to the Reich. The Inhabitants of the Latvian General district as forced Labourers in Greater Germany]. Latvijas zinātñu akadèmijas vēstis [News of the Latvian Academy of Sciences], 1990, no. 12, pp. 34-47. (In Latvian)

Latvija Otrajā pasaules karā (1939-1945) [Latvia during the Second World War (1939-1945)]. Ed. by D. Bleiere. Riga, Jumava Publ., 2008, 581 p. (In Latvian)

Generalkommissar (GK) in Kauen [Generalcommissar in Kovno], Schreiben betreffend: Einsatz litauischer Arbeitskräfte in Ostpreussen. An: Arbeitsamt Wilna [Letter concerning the application of lithuanian workforce in Eastern Prussia, Addressee: Labordepartement Wilna]. 26.11.1941. Lietuvos Centrinis Valstybès Archyvas (LCVA) [Lithuanian Central State Archive] (LCVA), R-626.1.16, p. 28. (In German)

Lumans V. O. Latvia in World War II. New York, Fordham University Press, 2006, 547 p.

Außerordentliche Kommission, Bericht über die Untersuchungen im Gebiet Daugavpils [Extraordinary Commission, Reprt about the findings in the Region of Dvinsk]. Latvijas Valsts Arhivs (LVA) [National Archive of Latvia], 101.6.20, p. 5.f. (In German, unpublished)

Dr. Speer, Denkschrift zur Frage der Umvolkung in den baltischen Landen. An: Generalkommissar in Reval [Dr. Speer, Memo about the question of Germanization in the Baltic Countries, Addressee: Districtcommissars in Reval, Riga and Kovno]. 22.11.1943. Latvijas Valsts Vestures Arhivs [Latvian Historical State Archive] (LVVA), P-69.1a.6, p. 186-194. (In German, unpublished)

Gebietskommissar in Dünaburg Schwung. Monatsbericht Mai/Juni 1942. An: GK in Riga [Regional Commissar in Dvinsk Schwung. Monthly Report of May/June 1942, Addressee: Districtcommissar in Riga]. 18.6.1942. Latvijas Valsts Vestures Arhivs [Latvian Historical State Archive] (LVVA), P-69.1a.18 (In German, unpublished)

Kreispolizeichef Ludsen, Schreiben betr.: Verwaltungsreform in Lettgallen. An: Generaldirektor des Innern. [District police commander, Letter concerning the administrational reform in Latgalia, Addressee: General Director of internal affairs] 21.3.1944. Latvijas Valsts Vestures Arhivs [Latvian State Archive] (LVVA), P-69.1a.29, p. 196. (In German, unpublished)

RKO Burmeister, Rundschreiben betreffend: Einheimische Volksgruppen [Reichcommissar Burmeister, Circular concerning indigeneous nations]. 27.7.1942. Latvijas Valsts Vestures Arhivs [Latvian Historical State Archive] (LVVA), P-69.1a.9 p. 12.f. (In German, unpublished)

RKO Trampedach, Schreiben betreffend: Meldung von einheimischen Schülern für den Reichsarbeitsdienst. An: RKO Abt. II Wissenschaft. [Reichcommissar Trampedach, Letter concerning the enrollment of local pupils for the Reichlaborservice, Addressee: Reichcommissar, departement of science]. 19.5.1942. Latvijas Valsts Vestures Arhivs [Latvian Historical State Archive] (LVVA), P-70.3.12, p. 4. (In German, unpublished)

Dr. Lenz, Denkschrift: Die rassische Zusammensetzung der Letten und ihre Beeinflussung durch die Deutschen [Dr. Lenz, Memo about the racial composition of the Latvians and the influence of the 
Germans]. Latvijas Valsts Vestures Arhivs [Latvian Historical State Archive] (LVVA), P-70.5.89, p. 6-11. (In German, unpublished)

Mēs apsudzam. Dokumenti un materiāli par hitlerisko okupantu un latviešu buržuāzisko nacionālistu ḷaundarībām Latvijas Padomju Socialistiskajā Republikā [We accuse. Documents and materials about the Hitleroccupation and the Latvian bourgeoise nationalistic crimes in the Latvian Socialist Soviet Republic]. Ed. by A. Kadikis. Riga, Liesma Publ., 1965, 146 p. (In Latvian)

Müller R.-D. Es begann am Kuban. Flucht-und Deportationsbewegungen in Osteuropa während des Rückzugs der deutschen Wehrmacht 1943/44 [It all began at the Kuban. Flight and Deportationmovements in Eastern Europe during the Retreat of the German Wehrmacht 1943/1944]]. Flucht und Vertreibung. Zwischen Aufrechnung und Verdrängung [Flight and Expulsion. Between Off-setting and Represion]. Eds R. Streibel, M. Alexander. Wien, Picus Publ., 1994, pp. 42-76. (In German)

Müller R.-D., Ueberschär G. R. Hitler's war in the East, 1941-1945. A critical assessment. New York, Berghahn Books, 2009, 506 p.

Myllyniemi S. Die Neuordnung der baltischen Länder 1941-1944: Zum nationalsozialistischen Inhalt der deutschen Besatzungspolitik [The New Order in the Baltic Countries 1941-1944: About the national socialist contend of the German Occupational policy]. Helsinki, Vammala Publ., 1973, 308 p. (In German)

Nationale und ethnische Konflikte in Estland und Lettland während der Zwischenkriegszeit [National and ethnic conflicts in Estonia and Latvia during the Interwar Period]. Ed. by D. Henning. Luneburg, CarlSchirren-Gesellschaft Publikationen [Publ. of the Society of Carl Schirren], 2009, 297 p. (In German)

Nikolaevič K. N. Kollaboracionizm ne imeet nacional'nosti. Učastie slavjan v nacistich formirovanijach na territorii okkuppirovannoj Latviii 1941-1945 [Collaboration does not have a nationality. The participation of slavonic people in the nazi formations in the territory of occupied Latvia 1941-1945]. Materialy meždunarodnoj naučnoj konferencii "Vtoraja Mirovaja vojna i strany Baltii.1939-1945 gg. [Materials of the international scientific conferences"The Second World War in the Baltic Countries 1939-1945"]. Riga, Retorika, 2008, pp. 60-64. (In Russian)

Piper E. Alfred Rosenberg. Hitlers Chefideologe [Alfred Rosenberg. Hitler's chief ideologist]. Munich, Blessing Publ., 2007, 830 p. (In German)

Plath T. Die lettische Region Latgale unter deutscher Besatzung 1941 bis 1944. Reaktionen der Bevölkerung [The Latvian Region of Latgale under German Occupation 1941 to 1944. Reactions of the local population]. Reichskommissariat Ostland. Tatort und Erinnerungsobjekt [Reichcommissariat Ostland. Site of Crime and object of memory]. Ed. by S.Lehmann. Vol. 8. Paderborn, Schöningh Publ., 2012, pp. 101-116. (In German)

Raßloff S. Fritz Sauckel: Hitlers "Muster-Gauleiter" und "Sklavenhalter" [Fritz Sauckel: Hitler's ModelGauleiter and Slaveholder]. Erfurt, Landeszentrale für politische Bildung Thüringen [Centre for political education Publ.], 2008, 151 p. (In German)

Reichskommissariat Ostland. Tatort und Erinnerungsobjekt [Reichcommissariat Ostland. Site of Crime and object of memory]. Ed. by S. Lehmann. Vol. 8. Paderborn, Schöningh Publ., 2012, 371 p. (In German)

Šteimanis J. Latgale 1939-1959 [Latgale 1939-1959]. Rezekne, Latgales Kulturas centra izdevnieciba, 2003, 136 p. (In Latvian)

Swain G. Between Stalin and Hitler. Class war and race war on the Dvina, 1940-46. London, Routledge Curzon Publ., 2004, 268 p.

Weiss-Wendt A. Murder without hatred. Estonians and the Holocaust. Syracuse; New York, Syracuse University Press, 2009, 476 p.

Wilhelm H.-H. Die Einsatzgruppe A der Sicherheitspolizei und des SD 1941/42 [Task force A of the Security Police and the Secret Service 1941/1942]. Frankfurt on Main; New York, P. Lang Publ., 1996, 597 p. (In German)

Zellhuber A. "Unsere Verwaltung treibt einer Katastrophe zu...". Das Reichsministerium für die besetzten Ostgebiete und die deutsche Besatzungsherrschaft in der Sowjetunion 1941-1945 ["Our Administration is moving towards the abyss"... The Reichministry of the Occupied eastern Territories and the German Occupation policy in the Soviet Union 1941-1945]. Munich, Vögel Publ., 2006, 414 p. (In German)

Received: 21 September 2016 Accepted: 26 January 2017 